\title{
Genetics of diabetic nephropathy
}

\author{
Bases genéticas da nefropatia diabética
}

Mariana P. Carpena', Dimitris V. Rados', Denise A. Sortica'', Bianca M. de Souza', André Fernandes Reis ${ }^{3}$, Luis Henrique Canani ${ }^{1,2}$, Daisy Crispim ${ }^{1,2}$

\section{SUMMARY}

The increasing prevalence of diabetes mellitus has led to a growing number of chronic complications including diabetic nephropathy (DN). In addition to its high prevalence, DN is associated with high morbidity and mortality especially due to cardiovascular diseases. It is well established that genetic factors play a role in the pathogenesis of DN and genetically susceptible individuals can develop it after being exposed to environmental factors. DN is probably a complex, polygenic disease. Two main strategies have been used to identify genes associated to DN: analysis of candidate genes, and more recently genome-wide scan. Great efforts have been made to identify these main genes, but results are still inconsistent with different genes associated to a small effect in specific populations. The identification of the main genes would allow the detection of those individuals at high risk for DN and better understanding of its pathophysiology as well. Arq Bras Endocrinol Metab. 2010;54(3):253-61

\section{Keywords}

Nephropathy; diabetes mellitus; genetics; genetic predisposition

\section{SUMÁRIO}

A crescente elevação na prevalência do diabetes melito (DM) acarretou em um aumento de suas complicações crônicas, entre elas a nefropatia diabética (ND). Além da elevada prevalência, a ND está associada à importante morbidade e mortalidade, principalmente por doenças cardiovasculares. É notória a contribuição genética na patogênese da ND, em que, na presença de fatores ambientais propícios, aqueles indivíduos geneticamente predispostos desenvolverão a doença. Trata-se de uma doença com provável transmissão genética do tipo poligênica e complexa. Duas estratégias principais têm sido utilizadas na busca dos genes associados à ND: a avaliação de genes candidatos e, mais recentemente, a utilização de genoma wide scan. Grande empenho tem sido realizado para identificar os principais genes associados à ND, mas os resultados ainda são heterogêneos com diferentes genes apresentando um efeito pequeno em populações específicas. A identificação dos principais genes permitiria prever os indivíduos de maior risco para o desenvolvimento da ND, além de possibilitar um melhor entendimento fisiopatológico da doença. Arq Bras Endocrinol Metab. 2010;54(3):253-61

Descritores

Nefropatia; diabetes melito; genética; predisposição genética

\section{INTRODUCTION}

$D$ iabetes mellitus (DM) is a set of metabolic disorders with different etiologies characterized by hyperglycemia resulting from defects in insulin secretion and/or action. In 2000, 171 million cases of DM worldwide were estimated, and that number is expected to increase to 366 million cases in 2030 (1). Concomitantly, the number of patients who develop chronic
Serviço de Endocrinologia do Hospital de Clínicas de Porto Alegre, Porto Alegre, RS, Brasil 2 Universidade Federal do Rio Grande do Sul (UFRGS), Porto Alegre, RS, Brasil ${ }^{3}$ Universidade Federal de São Paulo (Unifesp), São Paulo, SP, Brasil

Correspondence to:

Daisy Crispim

Rua Ramiro Barcelos, 2350 prédio $12,4^{\circ}$ andar 90035-003 - Porto Alegre, RS Brasil

dcmoreira@hcpa.ufrgs.br

Received on Sept/7/2009 Accepted on Feb/26/2010 complications of DM including diabetic nephropathy (DN) has grown.

Chronic kidney disease $(\mathrm{CKD})$ is defined as renal damage characterized by structural or functional abnormalities of the kidneys or glomerular filtration rate $(\mathrm{GFR})<60 \mathrm{~mL} / \mathrm{min} / 1.73 \mathrm{~m}^{2}$, with or without renal damage, over a period of at least three months, regardless of its causes (2). DN is characterized by a set of dia- 
betic pathophysiological changes, which begin with glomerular hyperfiltration and renal hypertrophy, and then progress to proteinuria and GFR reduction. Based on the levels of urine albumin excretion, in a didactic manner, DN has two phases: incipient nephropathy or the microalbuminuria phase with urine albumin excretion (UAE) ranging between $20-199 \mu \mathrm{g} / \mathrm{min}$ (or 30-300 $\mathrm{mg} / 24 \mathrm{~h})$; and, clinical nephropathy or the proteinuria phase with UAE > $199 \mu \mathrm{g} / \mathrm{min}(>300 \mathrm{mg} / 24 \mathrm{~h})$ or proteinuria $\geq 500 \mathrm{mg} / 24 \mathrm{~h}$. Microalbuminuria is considered a risk factor for DN progression (3).

About $20 \%$ to $30 \%$ of patients with type 1 and type 2 DM develop DN; however, a smaller proportion of patients with type $2 \mathrm{DM}$ will progress to end-stage renal disease (ESRD). Due to its high prevalence, the majority of patients requiring dialysis are type $2 \mathrm{DM}$. DN is the most common cause of ESRD in several countries $(4,5)$ but not all diabetic individuals will develop this complication. Those who do not develop DN in the first 15 years after disease onset seem to be genetically protected (6). Many environmental factors have been established as contributing to the development of $\mathrm{DN}$ while the role of others has yet to be clearly understood (7). It is known that factors such as hyperglycemia, arterial hypertension and/or dyslipidemia play a role in the development of DN in genetically predisposed individuals only.

The rates of hospitalization for all causes are about three times higher in patients with CKD than in those who do not have the disease (8). According to Pagano and cols. (9), patients with type $2 \mathrm{DM}$ with $\mathrm{DN}$ and peripheral arterial disease are 1.2 to 1.3 times more likely to be hospitalized (9). Besides its high disease burden, ESRD is associated with increased mortality, mainly due to cardiovascular causes (10). Reduced renal function is by itself an indicator of high mortality. Other concomitant risk factors such as hypertension and autonomic neuropathy can contribute to cardiovascular diseases (10). Even patients with DN initially characterized by microalbuminuria already have an increased risk for cardiovascular diseases and higher mortality (11). According to accumulating evidence the risk of developing DN and cardiovascular disease starts when UAE values are still within normal ranges (12). Some authors consider albuminuria a major risk factor for cardiovascular events rather than just a simple marker of DN progression (13) as some patients develop fatal cardiovascular events even before showing reduced renal function. In the metropolitan area of Porto Alegre, southern Brazil, $25 \%$ of new patients require dialysis due to $\mathrm{DM}$, and they show a high mortality rate during the first two years on dialysis (14).

It has not yet been clearly established by which mechanism some diabetic patients will progress towards loss of renal function and require dialysis while others will maintain normal renal function. Research has focused on seeking potential genetic alterations associated to CKD and ESRD. In fact, genetic evidence has been found in case-control association and linkage studies, and more recently using genome-wide scan (GWS). These studies support the assumption that onset, progression, and severity of DN can be in part attributed to genetic factors (15).

The identification of genes associated with $\mathrm{DN}$ will allow recognizing those individuals who are at high risk of developing this complication. It will also allow a better understanding of the mechanisms and progress of DN. Earlier and more aggressive therapies could be provided to high-risk individuals and thus reduce the associated high disease burden and mortality. Advances in pharmacogenetic research may help treatment choices by selecting renoprotective drugs according to individual haplotypes (16).

The present review discusses the main information available in literature that reaffirms the importance of genetic factors in DN. Some findings of our recent genetic studies are also summarized.

\section{GENETIC TRANSMISSION MODELS}

The genetic transmission mode of $\mathrm{DN}$ is still controversial. Theoretically, as in other diseases, it might occur in three distinct forms, which would lead to the development of DN $(6,17)$.

Monogenic form: mutations in a gene with a dominant role.

Oligogenic form: mutations/polymorphisms in a few genes would contribute in an independent and cumulative manner to increase susceptibility.

Polygenic form: alterations in many DNA loci, and each would have a small and cumulative effect on DN development.

Considering that $\mathrm{DN}$ is a multifactorial disease, the mode of transmission is likely to be polygenic, and genetic interaction with other environmental factors and clinical data such as duration of the DM, arterial hypertension, dyslipidemia, smoking would lead to the development of DN. Familial aggregation studies do not allow to clearly establish a mode of transmission but they provide evidence supporting that this is a polygen- 
ic complex disease $(6,17)$. On the other hand, studies using segregation analysis $(18,19)$ suggest that familial aggregation of DN is due mainly to the action of a main genetic locus. This effect would be consistent with a monogenic or oligogenic form where few genes would have greater effect on the phenotype.

Since several genes may be involved in the development of DN and many of them have not yet been identified, it is not possible to be completely sure about the exact heritability pattern in most cases.

\section{STRATEGIES FOR IDENTIFICATION OF GENES ASSOCIATED WITH DIABETIC NEPHROPATHY}

Genes that confer susceptibility to DN can be sought in different ways. A widely established method is the candidate gene approach. The search for candidate genes includes the study of polymorphisms in one or more genes potentially involved in the pathogenesis of the disease. This approach is useful even when the influence of a gene on disease development is small (17).

Candidate genes are often analyzed in case-control studies by comparing the frequency of polymorphisms/mutations in candidate genes among patients with and without the disease. This is an appropriate study for investigating complex genetic transmission, and it is especially useful in situations where the genetic influence is relatively low and disease-related alleles are common in a population (17). However, this approach is very sensitive to population stratification, which may lead to spurious associations. In the light of that it has been proposed that these studies should include a large sample to obtain very small p-values and be based on well-established a priori assumptions. This approach has allowed to describing many polymorphisms associated with $\mathrm{DN}$; however, the study results have been inconsistent. One of the most studied alterations is insertion/deletion on the angiotensin-converting enzyme $(A C E)$ gene. A meta-analysis has shown that the $\mathrm{D}$ allele is associated with high risk of DN (20).

Another approach used to analyze candidate genes is the transmission disequilibrium test (TDT). This approach is not influenced by population stratification, but information is required about the individuals studied and their parents, and only heterozygote parents are informative. The frequency of transmission of risk allele is compared to the expected $50 \%$. Its main limitation is having access to the individual and his/her parents, especially for type $2 \mathrm{DM}$ that has a late onset in life. In a case-con- trol study we demonstrated that the ectoenzyme nucleotide pyrophosphate phosphodiesterase (ENPPl) gene is associated with early development of ERSD in patients with type I DM (21), and using the TDT approach we confirmed this association was not due to population stratification (21). Araki and cols. (22) used the same approach to demonstrate that the APOE-epsilon 2 allele is associated with DN in type 1 diabetic individuals (22).

More recently candidate genes are being tested in prospective studies. This study design is less prone to survival bias than case control-studies but they are expensive and time-consuming. Alternatively, the authors are studying cohorts that have been followed up over a long period of time (23). The limitation of these studies is that they are not specifically designed to address a genetic effect of a specific gene.

The use of microarrays has enabled fast, accurate analysis of a large number of candidate genes and to perform GWS based on single nucleotide polymorphisms (SNPs). GWS can identify chromosomal regions that contain genes potentially involved in the genesis of a disease under study. Panels of microsatellite markers or SNPs, at $\sim 10$ centimorgans (cM) intervals throughout the genome, are genotyped in several generations of families of patients with DM, affected or not with DN. The markers that most commonly occur in family members affected with $\mathrm{DN}$ indicate the location of a functional variant associated with the disease and is in linkage disequilibrium with the marker. Given the difficulty of finding large families with several members affected by $\mathrm{DN}$, an alternative approach is to compare the observed and expected frequency of the markers in pairs of diabetic siblings concordant and discordant for DN. A major advantage over the candidate gene approach is that this approach can detect chromosomal regions containing genes that were not previously known to be implicated in the pathogenesis of DN. However, it has the disadvantage of only detecting genes that have a moderate or large effect (24). Using GWS we identified three polymorphisms located on chromosomes $9 \mathrm{q}$ and $\mathrm{ll} \mathrm{p}$ associated with $\mathrm{DN}$ in two different populations of patients with type $1 \mathrm{DM}(25)$.

\section{EVIDENCE FOR GENETIC PREDISPOSITION TO DIABETIC NEPHROPATHY}

\section{Familial aggregation of diabetic nephropathy}

Studies of familial aggregation have showed that some families are predisposed to DN (26-28). Studies on sib- 
lings with type 1 or type $2 \mathrm{DM}$ have reported that $\mathrm{DN}$ in one of the siblings is associated with around a 3- to 4-fold increase in the risk of DN in the other sibling $(29,30)$.

There appears to be a genetic inheritance contributing to the development of CKD. Forsblom and cols. (31) showed that the heritability $\left(h^{2}\right)$ of UAE rate is approximately $30 \%$ when analyzing non-diabetic children of type 2 diabetic individuals (31). This finding was corroborated by another study, which found that after adjustment for covariables such as sex, age, obesity and $\mathrm{DM}$, approximately $30 \%$ of the variability of albumincreatinine rate was due to genetic factors $(32)$.

The magnitude of the familial association cannot be attributed only to exposure to similar risk factors, suggesting there is a genetic component (33).

\section{Genes associated with diabetic nephropathy and different phenotypes}

although proteinuria and loss of renal function often occur concomitantly, there is evidence of different genetic predispositions for each condition (15). This can explain why some patients may have persistent proteinuria without progressing to loss of renal function (34) and other patients have loss of renal function without proteinuria or microalbuminuria $(15,35)$.

In genetic association studies, it is very important to clearly define the phenotype of interest. Most studies on heritability use albuminuria or proteinuria as a DN marker. In fact, loss of renal function measured by GFR is strongly associated with increased UAE. However, it is important to point out that a significant proportion of patients with DM develop loss of renal function but they maintain normoalbuminuria (35-37) and, conversely, some patients with clinical proteinuria maintain a stable GFR over the years (38).

UAE and GFR reduction are both genetically determined, but apparently independently (15). Langefeld and cols. (39) evaluated 310 families comprising 662 patients with type $2 \mathrm{DM}$ and found an $\mathrm{h}^{2}$ of 0.35 for UAE, and of 0.69 for GFR (39). These findings were similar to those described in other studies reporting an $\mathrm{h}^{2}$ of creatinine depuration of 0.63 among mono- and dizygotic twins (40).

\section{Studies of candidate genes}

One approach to identify genes associated to DN is the study of candidate genes. There are many studies of candidate genes for $\mathrm{DN}$ but the results are inconsistent
(Table 1). The choice of the gene to be studied depends on knowledge concerning its actions in DN pathophysiology such as those involving blood pressure control, severity of proteinuria or insulin resistance (41). Below we present our experience with this approach.

Type 2 DM patients with microalbuminuria have high serum levels of circulating fatty acids (50) compared to normoalbuminuric patients. Intestinal absorption of long-chain fatty acids is controlled by the intestinal fatty acid-binding protein 2 (FABP2). Thus, alterations in the gene that codifies the FABP2 can be candidates indicating predisposition to DN. A54T polymorphism (rs1799883) in FABP2 is associated with altered protein conformation, leading to greater affinity of the FABP2 protein for intestinal fatty acids with consequent serum increase. We genotyped this polymorphism in 1,042 Brazilian patients with type 2 DM. An association of the T allele was found at different stages of DN (Figure 1) (48). This association was replicated in an independent sample of 483 white American subjects with type $2 \mathrm{DM}$ (48).

Several studies analyzed the insertion/deletion (I/D) polymorphism in the ACE gene but the results about its association with $\mathrm{DN}$ in patients with type $\mathrm{l}$ and type $2 \mathrm{DM}$ were inconsistent, possibly due to ethnic differences of the populations studied (20). Besides, several studies used longer duration of DM as an inclusion criterion, which might predispose to survival bias, insofar as the possible genes associated with $\mathrm{DN}$ could also be associated with increased mortality. Therefore, we chose to investigate a potential association between I/D polymorphism in the ACE gene and the development of DN in 982 Brazilian patients with type $2 \mathrm{DM}$, taking into account the duration of their disease. In patients with 10 years or less of disease, having an allele D (DD/ID) resulted in an odds ratio (OR) of 2.66 (95\% CI 1.12$6.58, \mathrm{p}=0.015)$ for incipient $\mathrm{DN}$ and $3.19(95 \% \mathrm{CI}$ $1.18-9.30, \mathrm{p}=0.012)$ for overt DN. On the other hand, in patients with longer disease duration no increased risk for $\mathrm{DN}$ was seen associated with allele $\mathrm{D}(45)$.

Gene candidates for insulin resistance can also be considered DN candidates since insulin resistance is a common characteristic of patients with type 1 and type $2 \mathrm{DM}$ who present increased UAE $(51,52)$. The polymorphism in the ENPPI gene, previously known as $P C-1$, was found to be associated with insulin resistance (53). Based on this finding, a case-control study was conducted to assess the association between advanced DN and K121Q polymorphism (rs1805101) 
Table 1. Candidate genes for diabetic nephropathy

\begin{tabular}{|c|c|c|c|c|c|}
\hline Author & Gene & Polymorphism & OR (95\% Cl) & p-value & Case definitions \\
\hline Canani and cols., 2002 (21) & ENPP1/PC-1 & K121Q (rs1805101) & $2.3(1.2-4.4)$ & 0.014 & Patients with type $1 \mathrm{DM}$ with ESRD \\
\hline Leitao and cols., 2008 (42) & ENPP1/PC-1 & K121Q (rs1805101) & $1.06(0.73-1.54)$ & 0.830 & Type 2 DM with micro- or macroalbuminuria \\
\hline Ng and cols., 2002 (43) & GLUT1 & $\begin{array}{c}\text { Xbal } \\
\text { enhancer-2 }\end{array}$ & $\begin{array}{l}1.83(1.01-3.33) \\
2.38(1.16-4.90)\end{array}$ & $\begin{array}{l}0.044 \\
0.036\end{array}$ & $\begin{array}{l}\text { Patients with type } 1 \text { DM with persistent } \\
\text { proteinuria or ESRD }\end{array}$ \\
\hline Santos and cols., 2006 (44) & CATALASE & $-262 \mathrm{C} / \mathrm{T}$ (rs35448603) & $0.92(0.63-1.37)$ & 0.776 & $\begin{array}{l}\text { White patients with type } 2 \text { DM with micro- or } \\
\text { macroalbuminuria or ESRD }\end{array}$ \\
\hline Canani and cols., 2005 (45) & ACE & Ins/Del polymorphism & $\begin{array}{l}2.66(1.12-6.58) \\
3.19(1.18-9.30)\end{array}$ & $\begin{array}{l}0.015 \\
0.012\end{array}$ & $\begin{array}{l}\text { Type } 2 \text { DM with less than } 24 \text { years of disease: } \\
\text { incipient and overt DN, respectively }\end{array}$ \\
\hline Santos and cols., 2005 (46) & CYBA & p22phox C242T (rs4673) & $2.24(1.15-4.37)$ & 0.045 & $\begin{array}{l}\text { White patients with type } 2 \mathrm{DM} \text {, smokers, with } \\
\text { micro- or macroalbuminuria or ESRD }\end{array}$ \\
\hline Santos and cols., 2005 (47) & RAGE & $\begin{array}{l}-429 \mathrm{C}(\mathrm{rs} 1800625) \\
-374 \mathrm{~A}(\mathrm{rs} 1800624)\end{array}$ & $\begin{array}{l}1.31(0.62-2.76) \\
0.77(0.40-1.45)\end{array}$ & $\begin{array}{l}0.720 \\
0.270\end{array}$ & $\begin{array}{l}703 \text { Brazilians with type } 2 \text { DM ( } 520 \text { Caucasians) } \\
\text { and } 183 \text { of African ascendance with micro- or } \\
\text { macroalbuminuria or ESRD }\end{array}$ \\
\hline Canani and cols., 2005 (48) & FABP-2 & A54T (rs1799883) & $2.4(1.1-5.4)$ & 0.005 & $\begin{array}{l}\text { Type } 2 \text { DM with microalbuminuria or persistent } \\
\text { proteinuria or ESRD }\end{array}$ \\
\hline Caramori and cols., 2003 (49) & PPAR $\gamma 2$ & Pro12Ala (rs1801282) & $0.465(0.229-0.945)$ & 0.034 & Type 2 DM with CKD and normoalbuminuria \\
\hline
\end{tabular}

CKD: Chronic kidney disease; DM: diabetes mellitus; DN: diabetic nephropathy; ESRD: end-stage renal disease; OR: odds ratio; Cl: confidence interval.

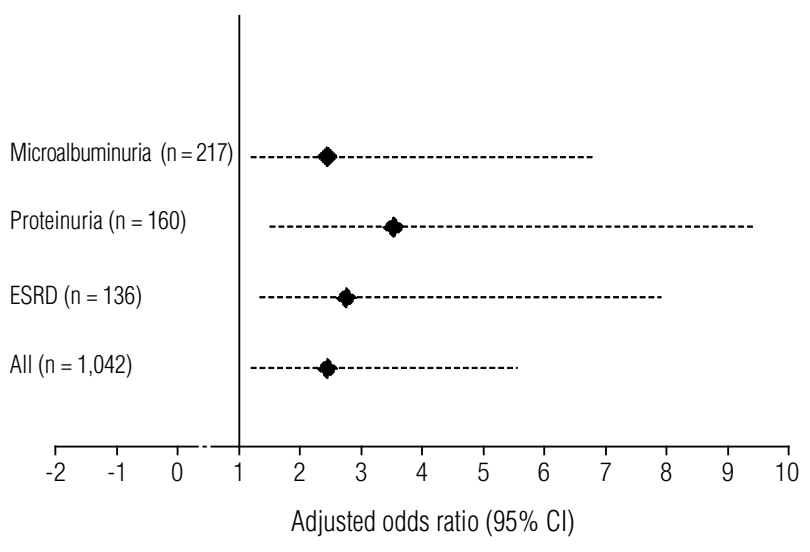

Figure 1. Odds ratio $(\bullet)$ with $95 \%$ confidence intervals (dotted line) for the presence of A54T polymorphism in FABP2 at the different stages of renal involvement adjusted for diabetes duration, body mass index, arterial hypertension, HbA1c, and cholesterol levels. ESRD: end-stage renal disease.

in the ENPPI gene of patients with type $1 \mathrm{DM}$. The proportion of patients with the variant $Q$ was $21.5 \%$ in the control group, $31.5 \%$ in those with proteinuria, and $32.2 \%$ in those with ESRD $(\mathrm{p}=0.012)$. In a stratified analysis for DM duration ( $<24$ or $\geq 24$ years of DM), the risk of early onset of ESRD for patients with the variant $\mathrm{Q}$ was 2.3 times greater than for those without the variant Q (95\% CI 1.2-4.4) and it was not associated with late onset ESRD (21). This association was confirmed using TDT, which showed that this association was not due to population stratification (21).

Polymorphisms in GLUTI gene associated with DN were also examined. GLUTl is a glucose transporter in the kidneys and it has been associated with early kidney alterations leading to proteinuria. We studied 230 controls (patients with DMl, disease duration of at least 15 years and normoalbuminuria), and 262 cases ( $151 \mathrm{pa}-$ tients with persistent proteinuria and 111 with ESRD). The homozygosis for the $\mathrm{XbaI}(-)$ allele was associated with a discrete increased risk for DN when compared to other genotypes combined [OR 1.83 (95\% CI 1.01$3.33)$ ]. A significant difference in genotype distribution among cases and controls was seen for the enhancer-2 SNPI $(\mathrm{p}=0.036)$. There was an excess of genotype AA among the cases (10.7\%) compared to controls (4.8\%). These homozygous individuals presented an increased risk for DN compared to AG and GG genotypes combined [OR 2.38 (95\% CI 1.16-4.90)] (43).

Other studies analyzed different genes and did not find an association with DN (Table 1). One of these studies showed that, when patients were stratified for smoking, allele $\mathrm{T}$ (p22phox C242T polymorphism; rs4673) was more frequently seen in smokers with ESRD or persistent proteinuria than in normoalbuminuric patients ( $43 \%$ vs. $32 \% ; \mathrm{p}=0.045)$. The multiple logistic regression analysis confirmed that CT and TT genotypes were independently associated with a greater risk of overt $\mathrm{DN}$ among smokers $(\mathrm{OR}=6.76 ; 95 \% \mathrm{CI}$ 1.83-25.02) (46).

Our experience with candidate genes allowed us to identifying some genes that can be related to the development and severity of DN. 


\section{Genome-wide scan studies}

Recent GWS studies have demonstrated chromosomal regions potentially associated with DN. Table 2 shows the studies using a GWS approach. In DN concordant Pima Indians, a potential association was seen between chromosome $7 \mathrm{q}$ and phenotype of $\mathrm{DN}$. The area between two markers (D7S500 and D7S1804), in 144 $\mathrm{cM}$, showed the strongest association, with a LOD score of 2.04. Two other susceptibility loci were also found in chromosomes 20 (LOD score of 1.83) and 3 (LOD score of 1.48) (54).

Genes located in chromosomes $22 \mathrm{q}, 5 \mathrm{q}$, and $7 \mathrm{q}$ might be involved in the determination of UAE severity in patients with and without DM (58). In a genomewide association study, regions in chromosomes 19 and $2 \mathrm{q}$ were identified as associated with proteinuria and ESRD in patients with type $1 \mathrm{DM}(60)$. A locus in chromosome lq was associated with ESRD only, while a locus in chromosome $20 \mathrm{p}$ was associated with proteinuria only (60). Two independent loci were identified in chromosome 3q, $59 \mathrm{cM}$ from each other, one associated with proteinuria and the other with ESRD (60).

A genome-wide association study with 360,000 SNPs using the microarray Affymetrix 5.0 was recently conducted in two independent cohorts of Caucasians patients with type $1 \mathrm{DM}$ (25). SNPs that were highly significant in the two cohorts were selected for further analyses. Eleven SNPs located at 4 loci were closely as- sociated with DN $\left(\mathrm{p}<1 \times 10^{-5}\right)$ (Table 3$)$. Some of these associations found in the cross-sectional study were confirmed in a prospective sample of the Diabetes Control and Complications Trial/Epidemiology of Diabetes Interventions and Complications (DCCT/ EDIC). Three of the 11 initial SNPs had their association confirmed, two were borderline and the remaining did not show a significant association with the development of DN (proteinuria or CKD) (25) (Table 4).

Other authors have reported an association of different chromosomal regions using GWS approach to search for DN related genes (Table 2) $(55-57,59)$.

\section{CONCLUSION AND PERSPECTIVES}

In conclusion, clinical and epidemiological studies have evidenced a genetic component of DN. However, no specific gene has been able to explain most DN cases yet. The results of studies that identified genes or genome regions associated with $\mathrm{DN}$ were quite inconsistent. The lack of more consistent results is probably due to different factors. Most genetic studies have been performed in selected populations but they are heterogeneous between them. It should also be pointed out that an isolated candidate gene is sought when various genes are probably involved and possibly interlinked. Joint efforts are essential to achieve robust findings in the study of genetics of DN. In the light of remarkable

Table 2. Genome-wide scan studies for genes associated with diabetic nephropathy

\begin{tabular}{|c|c|c|c|}
\hline Author & Population studied & Regions associated & Phenotype \\
\hline Imperatore and cols., 1998 (54) & Pima Indians- 98 siblings with DM2, concordant for ND & $7 q, 3$ and 20 & Albuminuria or proteinuria \\
\hline Vardarli and cols., 2002 (55) & 125 patients with DM2 & $18 q 22.3-23$ & Albuminuria \\
\hline Tanaka and cols., 2003 (56) & $\begin{array}{l}\text { Japanese with DM2 grouped into cases (with DR and DN) and } \\
\text { controls (with DR and without DN) }\end{array}$ & $16 q 13$ & Albuminuria \\
\hline Bowden and cols., 2004 (57) & 266 siblings with DM2, African-Americans, concordant for DN & $3 q, 7 p$ and $18 q$ & CKD \\
\hline $\begin{array}{l}\text { Krolewski and cols., } 2006 \\
\text { (58) }\end{array}$ & $\begin{array}{l}59 \text { Caucasian families, } 1 \text { African-American, and } 3 \\
\text { Hispanic. Members with and without DM2 }\end{array}$ & $22 q, 5 q$ and $7 q$ & Albuminuria \\
\hline lyengar and cols., 2007 (59) & $\begin{array}{l}\text { 1,227 subjects from } 378 \text { families with } \\
\text { DM1 or DM2, concordant or discordant for DN }\end{array}$ & $\begin{array}{c}2 \mathrm{q} 14.1,7 \mathrm{q} 21.1 \text { and } 15 \mathrm{q} 26.3 \\
7 \mathrm{q} 21.3,10 \mathrm{p} 15.3,14 \mathrm{q} 23.1 \text { and } 18 \mathrm{q} 22.3\end{array}$ & $\begin{array}{l}\text { Albuminuria } \\
\text { Proteinuria or ESRD }\end{array}$ \\
\hline Rogus and cols., 2008 (60) & Sibling concordant for DM1 and discordant for ND & $\begin{array}{c}19 q, 2 q \text { and } 3 q \\
1 q \\
20 p\end{array}$ & $\begin{array}{c}\text { Proteinuria and ESRD } \\
\text { ESRD } \\
\text { Proteinuria }\end{array}$ \\
\hline Pezzolesi and cols., 2009 (25) & Type 1 DM patients with DN (cases) and without DN (controls) & $\begin{array}{c}7 p-\text { CPVL/CHN2 } \\
9 q-\text { locus FRMD3 } \\
11 p-\text { locus CARS } \\
13 q\end{array}$ & Proteinuria and ESRD \\
\hline
\end{tabular}

CKD: Chronic kidney disease; DM: diabetes mellitus; DN: diabetic nephropathy; DR: diabetic retinopathy; ESRD: end-stage renal disease. 
Table 3. Single nucleotide polymorphisms associated with diabetic nephropathy in a population of GoKinD

\begin{tabular}{|c|c|c|c|c|c|c|c|c|c|c|}
\hline \multirow{3}{*}{ SNP } & \multirow{3}{*}{ Chromosome } & \multirow{3}{*}{ Position (Mb) } & \multirow{3}{*}{ Nearest gene } & \multirow{3}{*}{ Risk Allele } & \multicolumn{6}{|c|}{ Frequencies of risk alleles for cases and controls } \\
\hline & & & & & \multicolumn{3}{|c|}{ GWU* GoKinD } & \multicolumn{3}{|c|}{ JDC** GoKinD } \\
\hline & & & & & Controls & Cases & p-value & Controls & Cases & p-value \\
\hline N & & & & & 413 & 379 & & 472 & 441 & \\
\hline rs39059 & $7 p$ & 29.2 & CPVL/CHN2 & $A(G)$ & 0.61 & 0.69 & $8.8 \times 10^{-4}$ & 0.60 & 0.67 & $1.7 \times 10^{-3}$ \\
\hline rs39075 & $7 p$ & 29.2 & CPVL/CHN2 & $G(A)$ & 0.57 & 0.66 & $2.0 \times 10^{-4}$ & 0.57 & 0.64 & $8.2 \times 10^{-4}$ \\
\hline rs1888747 & $9 q$ & 85.3 & FRMD3 & $\mathrm{G}(\mathrm{C})$ & 0.68 & 0.73 & $3.6 \times 10^{-3}$ & 0.66 & 0.74 & $4.4 \times 10^{-5}$ \\
\hline rs 10868025 & $9 q$ & 85.4 & FRMD3 & $A(G)$ & 0.59 & 0.66 & $1.9 \times 10^{-3}$ & 0.56 & 0.66 & $7.2 \times 10^{-5}$ \\
\hline rs739401 & $11 p$ & 3.0 & CARS & $C(T)$ & 0.46 & 0.54 & $4.7 \times 10^{-4}$ & 0.49 & 0.55 & $3.6 \times 10^{-3}$ \\
\hline rs451041 & $11 p$ & 3.0 & CARS & $A(G)$ & 0.46 & 0.54 & $6.9 \times 10^{-4}$ & 0.48 & 0.56 & $1.3 \times 10^{-3}$ \\
\hline rs1041466 & $13 q$ & 109.0 & No gene & $G(A)$ & 0.39 & 0.47 & $3.6 \times 10^{-3}$ & 0.43 & 0.51 & $2.7 \times 10^{-4}$ \\
\hline rs1411766/rs17412858 & $13 q$ & 109.1 & No gene & $A(G) G(A)$ & 0.31 & 0.39 & $8.5 \times 10^{-4}$ & 0.32 & 0.40 & $6.4 \times 10^{-4}$ \\
\hline rs6492208/rs2391777 & $13 q$ & 109.1 & No gene & $T(C) G(A)$ & 0.55 & 0.62 & $8.7 \times 10^{-3}$ & 0.56 & 0.65 & $1.9 \times 10^{-4}$ \\
\hline rs7989848 & $13 q$ & 109.1 & No gene & $A(G)$ & 0.49 & 0.56 & $2.0 \times 10^{-3}$ & 0.50 & 0.57 & $1.1 \times 10^{-3}$ \\
\hline rs9521445 & $13 q$ & 109.1 & No gene & $A(C)$ & 0.47 & 0.54 & $2.1 \times 10^{-3}$ & 0.47 & 0.55 & $4.2 \times 10^{-4}$ \\
\hline
\end{tabular}

* GWU - George Washington University;

** JDC - Joslin Diabetes Center.

Table 4. Single nucleotide polymorphisms associated with diabetic nephropathy in a population of DCCT/EDIC

\begin{tabular}{|c|c|c|c|c|c|c|c|}
\hline SNP & Chromosome & Position (Mb) & Nearest gene & Risk allele & Allele frequency & $\begin{array}{c}\text { p-value } \\
\text { (unicaudal) }\end{array}$ & Hazard ratios \\
\hline rs39075 & $7 p$ & 29.2 & CPVL/CHN2 & $G$ & 0.60 & NS & 0.85 \\
\hline rs1888746 & $9 q$ & 85.3 & FRMD3 & C & 0.70 & 0.02 & 1.33 \\
\hline rs13289150 & $9 q$ & 85.4 & FRMD3 & A & 0.62 & 0.05 & 1.23 \\
\hline rs451041 & $11 p$ & 3.0 & CARS & A & 0.51 & 0.01 & 1.32 \\
\hline rs1041466 & $13 q$ & 109.0 & No gene & G & 0.47 & 0.11 & 1.22 \\
\hline rs1411766 & $13 q$ & 109.1 & No gene & A & 0.36 & 0.11 & 1.17 \\
\hline rs6492208 & $13 q$ & 109.1 & No gene & $\mathrm{T}$ & 0.61 & NS & 0.90 \\
\hline rs7989848 & $13 q$ & 109.1 & No gene & A & 0.53 & NS & 0.93 \\
\hline
\end{tabular}

advances in this area of study, we hope that in the near future patients at high risk for developing DN could be identified and benefited with earlier specific therapies. We also expect to see a consequent reduction in disease burden and mortality due to this serious complication. New pharmacogenomic developments will contribute to better treatment choices for DN and, more importantly, will help preventing it based on an individual's genetic characteristics.

Disclosure: no potential conflict of interest relevant to this article was reported.

\section{REFERENCES}

1. Wild S, Roglic G, Green A, Sicree R, King H. Global prevalence of diabetes: estimates for the year 2000 and projections for 2030 . Diabetes Care. 2004;27(5):1047-53.
2. Levey AS, Eckardt KU, Tsukamoto Y, Levin A, Coresh J, Rossert J, et al. Definition and classification of chronic kidney disease: a position statement from Kidney Disease: Improving Global Outcomes (KDIGO). Kidney Int. 2005;67(6):2089-100.

3. Murussi M, Murussi N, Campagnolo N, Silveiro SP. [Early detection of diabetic nephropathy]. Arq Bras Endocrinol Metabol. 2008;52(3):442-51.

4. Molitch ME, DeFronzo RA, Franz MJ, Keane WF, Mogensen CE, Parving HH. Diabetic nephropathy. Diabetes Care. 2003;26 Suppl 1:S94-8.

5. Bloomgarden ZT. Diabetic nephropathy. Diabetes Care. 2008;31(4):823-7.

6. Krolewski AS. Genetics of diabetic nephropathy: evidence for major and minor gene effects. Kidney Int. 1999;55(4):1582-96.

7. Murussi M, Coester A, Gross JL, Silveiro SP. Diabetic nephropathy in type 2 diabetes mellitus: risk factors and prevention. Arq Bras Endocrinol Metabol. 2003;47(3):207-19.

8. United States Renal Data System. 2007 [cited 2009 May 14]; Available from: http://www.usrds.org

9. Pagano E, Bo S, Petrinco M, Rosato R, Merletti F, Gregori D. Factors affecting hospitalization costs in Type 2 diabetic patients. J Diabetes Complications. 2009;23(1):1-6. 
10. Gross JL, Silveiro SP, Canani LH, Friedman R, Leitao CB, Azevedo MJ. [Diabetic nephropathy and cardiac disease]. Arq Bras Endocrinol Metabol. 2007;51(2):244-56.

11. Zanella M. Microalbuminuria: cardiovascular and renal risk factors underestimated in clinical practice. Arq Bras Endocrinol Metabol. 2005;50(2):313-21.

12. Leitao CB, Canani LH, Bolson PB, Molon MP, Silveiro SP, Gross $\mathrm{JL}$. [What values should be used to diagnose microalbuminuria in patients with diabetes mellitus?]. Arq Bras Endocrinol Metabol. 2006;50(2):322-6.

13. Garg JP, Bakris GL. Microalbuminuria: marker of vascular dysfunction, risk factor for cardiovascular disease. Vasc Med. 2002;7(1):35-43.

14. Bruno RM, Gross JL. Prognostic factors in Brazilian diabetic patients starting dialysis: a 3.6-year follow-up study. J Diabetes Complications. 2000;14(5):266-71.

15. Placha G, Canani LH, Warram JH, Krolewski AS. Evidence for different susceptibility genes for proteinuria and ESRD in type 2 diabetes. Adv Chronic Kidney Dis. 2005;12(2):155-69.

16. Penno G, Chaturvedi N, Talmud PJ, Cotroneo P, Manto A, Nannipieri $M$, et al. Effect of angiotensin-converting enzyme (ACE) gene polymorphism on progression of renal disease and the influence of ACE inhibition in IDDM patients: findings from the EUCLID Randomized Controlled Trial. EURODIAB Controlled Trial of Lisinopril in IDDM. Diabetes. 1998;47(9):1507-11.

17. Adler SG, Pahl M, Seldin MF. Deciphering diabetic nephropathy: progress using genetic strategies. Curr Opin Nephrol Hypertens. 2000;9(2):99-106.

18. Imperatore G, Knowler WC, Pettitt DJ, Kobes S, Bennett PH, Hanson RL. Segregation analysis of diabetic nephropathy in Pima Indians. Diabetes. 2000;49(6):1049-56.

19. Fogarty DG, Hanna LS, Wantman M, Warram JH, Krolewski AS, Rich SS. Segregation analysis of urinary albumin excretion in families with type 2 diabetes. Diabetes. 2000;49(6):1057-63.

20. Ng DP, Tai BC, Koh D, Tan KW, Chia KS. Angiotensin-I converting enzyme insertion/deletion polymorphism and its association with diabetic nephropathy: a meta-analysis of studies reported between 1994 and 2004 and comprising 14,727 subjects. Diabetologia. 2005;48(5):1008-16.

21. Canani LH, Ng DP, Smiles A, Rogus JJ, Warram JH, Krolewski AS. Polymorphism in ecto-nucleotide pyrophosphatase/phosphodiesterase 1 gene (ENPP1/PC-1) and early development of advanced diabetic nephropathy in type 1 diabetes. Diabetes. 2002;51(4):1188-93.

22. Araki S, Moczulski DK, Hanna L, Scott LJ, Warram JH, Krolewski AS. APOE polymorphisms and the development of diabetic nephropathy in type 1 diabetes: results of case-control and familybased studies. Diabetes. 2000;49(12):2190-5.

23. Hadjadj S, Fumeron F, Roussel R, Saulnier PJ, GalloisY, Ankotche A, et al. Prognostic value of the insertion/deletion polymorphism of the ACE gene in type 2 diabetic subjects: results from the Noninsulin-dependent Diabetes, Hypertension, Microalbuminuria or Proteinuria, Cardiovascular Events, and Ramipril (DIABHYCAR), Diabete de type 2, Nephropathie et Genetique (DIAB2NEPHROGENE), and Survie, Diabete de type 2 et Genetique (SURDIAGENE) studies. Diabetes Care. 2008;31(9):1847-52.

24. Conway BR, Savage DA, Maxwell AP. Identifying genes for diabetic nephropathy - current difficulties and future directions. Nephrol Dial Transplant. 2006;21(11):3012-7.

25. Pezzolesi MG, Poznik GD, Mychaleckyj JC, Paterson AD, Barati MT, Klein JB, et al. Genome-wide association scan for diabetic nephropathy susceptibility genes in type 1 diabetes. Diabetes. 2009;58(6):1403-10.

26. Faronato PP, Maioli M, Tonolo G, Brocco E, Noventa F, Piarulli F, et al. Clustering of albumin excretion rate abnormalities in Cauca- sian patients with NIDDM. The Italian NIDDM Nephropathy Study Group. Diabetologia. 1997;40(7):816-23.

27. Seaquist ER, Goetz FC, Rich S, Barbosa J. Familial clustering of diabetic kidney disease. Evidence for genetic susceptibility to diabetic nephropathy. N Engl J Med. 1989;320(18):1161-5.

28. Agius E, Attard G, Shakespeare L, Clark P, Vidya MA, Hattersley AT, et al. Familial factors in diabetic nephropathy: an offspring study. Diabet Med. 2006;23(3):331-4.

29. Canani LH, Gerchman F, Gross JL. Familial clustering of diabetic nephropathy in Brazilian type 2 diabetic patients. Diabetes. 1999;48(4):909-13.

30. Harjutsalo V, Katoh S, Sarti C, Tajima N, Tuomilehto J. Populationbased assessment of familial clustering of diabetic nephropathy in type 1 diabetes. Diabetes. 2004;53(9):2449-54.

31. Forsblom CM, Kanninen T, Lehtovirta M, Saloranta C, Groop LC. Heritability of albumin excretion rate in families of patients with Type II diabetes. Diabetologia. 1999;42(11):1359-66.

32. Fogarty DG, Rich SS, Hanna L, Warram JH, Krolewski AS. Urinary albumin excretion in families with type 2 diabetes is heritable and genetically correlated to blood pressure. Kidney Int. 2000;57(1):250-7.

33. Khoury MJ, BeatyTH, Liang KY. Can familial aggregation of disease be explained by familial aggregation of environmental risk factors? Am J Epidemiol. 1988;127(3):674-83.

34. Friedman R, De Azevedo MJ, Gross JL. Is endogenous creatinine clearance still a reliable index of glomerular filtration rate in diabetic patients? Braz J Med Biol Res. 1988;21(5):941-4.

35. Kramer CK, Leitao CB, Pinto LC, Silveiro SP, Gross JL, Canani LH. Clinical and laboratory profile of patients with type 2 diabetes with low glomerular filtration rate and normoalbuminuria. Diabetes Care. 2007;30(8):1998-2000.

36. Middleton RJ, Foley RN, Hegarty J, Cheung CM, McElduff P, Gibson JM, et al. The unrecognized prevalence of chronic kidney disease in diabetes. Nephrol Dial Transplant. 2006;21(1):88-92.

37. Maclsaac RJ, Tsalamandris C, Panagiotopoulos S, Smith TJ, McNeil KJ, Jerums G. Nonalbuminuric renal insufficiency in type 2 diabetes. Diabetes Care. 2004;27(1):195-200.

38. Friedman R, Gross JL. Evolution of glomerular filtration rate in proteinuric NIDDM patients. Diabetes Care. 1991;14(5):355-9.

39. Langefeld CD, Beck SR, Bowden DW, Rich SS, Wagenknecht LE, Freedman BI. Heritability of GFR and albuminuria in Caucasians with type 2 diabetes mellitus. Am J Kidney Dis. 2004;43(5): 796-800.

40. Hunter DJ, Lange M, Snieder H, MacGregor AJ, Swaminathan R, Thakker RV, et al. Genetic contribution to renal function and electrolyte balance: a twin study. Clin Sci (Lond). 2002;103(3):259-65.

41. Freedman BI, Satko SG. Genes and renal disease. Curr Opin Nephrol Hypertens. 2000;9(3):273-7.

42. Leitao $\mathrm{CB}$, Nabinger GB, Krahe AL, Bolson PB, Gerchman F, Friedman $R$, et al. The role of K1210 ENPP1 polymorphism in diabetes mellitus and its complications. Braz $\mathrm{J}$ Med Biol Res. 2008;41(3):229-34.

43. Ng DP, Canani L, Araki S, Smiles A, Moczulski D, Warram JH, et al. Minor effect of GLUT1 polymorphisms on susceptibility to diabetic nephropathy in type 1 diabetes. Diabetes. 2002;51(7):2264-9.

44. dos Santos KG, Canani LH, Gross JL, Tschiedel B, Souto KE, Roisenberg I. The catalase $-262 \mathrm{C} / \mathrm{T}$ promoter polymorphism and diabetic complications in Caucasians with type 2 diabetes. Dis Markers. 2006;22(5-6):355-9.

45. Canani LH, Costa LA, Crispim D, Gonçalves Dos Santos K, Roisenberg I, Lisboa HR, et al. The presence of allele D of angiotensinconverting enzyme polymorphism is associated with diabetic nephropathy in patients with less than 10 years duration of Type 2 diabetes. Diabet Med. 2005;22(9):1167-72. 
46. Santos KG, Canani LH, Gross JL, Tschiedel B, Souto KE, Roisenberg I. Relationship of p22phox C242T polymorphism with nephropathy in type 2 diabetic patients. J Nephrol. 2005;18(6):733-8.

47. dos Santos KG, Canani LH, Gross JL, Tschiedel B, Pires Souto KE, Roisenberg I. The -374A allele of the receptor for advanced glycation end products gene is associated with a decreased risk of ischemic heart disease in African-Brazilians with type 2 diabetes. Mol Genet Metab. 2005;85(2):149-56.

48. Canani LH, Capp C, Ng DP, Choo SG, Maia AL, Nabinger GB, et al. The fatty acid-binding protein-2 A54T polymorphism is associated with renal disease in patients with type 2 diabetes. Diabetes. 2005;54(11):3326-30.

49. Caramori ML, Canani LH, Costa LA, Gross JL. The human peroxisome proliferator-activated receptor gamma2 (PPARgamma2) Pro12Ala polymorphism is associated with decreased risk of diabetic nephropathy in patients with type 2 diabetes. Diabetes. 2003;52(12):3010-3.

50. Perassolo MS, Almeida JC, Pra RL, Mello VD, Maia AL, Moulin CC, et al. Fatty acid composition of serum lipid fractions in type 2 diabetic patients with microalbuminuria. Diabetes Care. 2003;26(3):613-8.

51. Yip J, Mattock MB, Morocutti A, Sethi M, Trevisan R, Viberti G. Insulin resistance in insulin-dependent diabetic patients with microalbuminuria. Lancet. 1993;342(8876):883-7.

52. Groop L, Ekstrand A, Forsblom C, Widen E, Groop PH, Teppo AM, et al. Insulin resistance, hypertension and microalbuminuria in patients with type 2 (non-insulin-dependent) diabetes mellitus. Diabetologia. 1993;36(7):642-7.

53. Pizzuti A, Frittitta L, Argiolas A, Baratta R, Goldfine ID, Bozzali M, et al. A polymorphism (K1210) of the human glycoprotein PC-1 gene coding region is strongly associated with insulin resistance. Diabetes. 1999;48(9):1881-4.

54. Imperatore G, Hanson RL, Pettitt DJ, Kobes S, Bennett PH, Knowler WC. Sib-pair linkage analysis for susceptibility genes for microvascular complications among Pima Indians with type 2 diabetes. Pima Diabetes Genes Group. Diabetes. 1998;47(5):821-30.

55. Vardarli I, Baier LJ, Hanson RL, Akkoyun I, Fischer C, Rohmeiss $P$, et al. Gene for susceptibility to diabetic nephropathy in type 2 diabetes maps to 18q22.3-23. Kidney Int. 2002;62(6):2176-83.

56. Tanaka N, Babazono T, Saito S, Sekine A, Tsunoda T, Haneda M, et al. Association of solute carrier family 12 (sodium/chloride) member 3 with diabetic nephropathy, identified by genomewide analyses of single nucleotide polymorphisms. Diabetes. 2003;52(11):2848-53.

57. Bowden DW, Colicigno CJ, Langefeld CD, Sale MM, Williams A, Anderson PJ, et al. A genome scan for diabetic nephropathy in African Americans. Kidney Int. 2004;66(4):1517-26.

58. Krolewski AS, Poznik GD, Placha G, Canani L, Dunn J, Walker W, et al. A genome-wide linkage scan for genes controlling variation in urinary albumin excretion in type II diabetes. Kidney Int. 2006;69(1):129-36.

59. lyengar SK, Abboud HE, Goddard KA, Saad MF, Adler SG, Arar $\mathrm{NH}$, et al. Genome-wide scans for diabetic nephropathy and albuminuria in multiethnic populations: the family investigation of nephropathy and diabetes (FIND). Diabetes. 2007;56(6):1577-85.

60. Rogus JJ, Poznik GD, Pezzolesi MG, Smiles AM, Dunn J, Walker W, et al. High-density single nucleotide polymorphism genomewide linkage scan for susceptibility genes for diabetic nephropathy in type 1 diabetes: discordant sibpair approach. Diabetes. 2008;57(9):2519-26. 